\title{
Dutch Curse on Indonesia: Energy Poverty From Asian Development Bank (ADB) Loans
}

\author{
Muhammad Amir Ingratubun ${ }^{1 *}$, Akhmad Fauzi², R. Nunung Nuryartono ${ }^{3}$ \\ ${ }^{1,2,3}$ Regional and Rural Development Planning Department, IPB University, Bogor, West Java, Indonesia. \\ ${ }^{*}$ Corresponding author: aingratubun@gmail.com; ingratubun_ma@apps.ipb.ac.id
}

\begin{abstract}
ADB is a multilateral regional development bank similar to the World Bank. It takes an average of over 5-year to disburse the loan funds because of conditionalities compared with one day by commercial banks. During which, the funds stay in the banks and gain compounded interest. Development studies have mostly overlooked these gains and their impacts. ADB loans attribute about $0.3 \%$ of Indonesia's energy poverty, we reviewed the disbursement delay impacts on energy poverty involving $35 \mathrm{ADB}$ energy loan projects with over $\$ 5.2$ billion from 1971 to 2017 . We applied a non-econometric method adopting project and portfolio management principles. With average ADB energy loans to Indonesia of $0.127 \%$ of GDP, the results showed ADB loans initially helped Indonesia reduce energy poverty by $30 \%$, but at $0.006 \%$ of GDP increasing it back and continues to aggravate beyond $0.127 \%$ of GDP by $60 \%$. This exhibits that for each 1\% of GDP increase in ADB loans, they increase $8 \%$ energy poverty. Disbursement delays worsen this to $11 \%$. Because of this, Indonesia suffers Dutch disease going in reverse which we term as Dutch Curse because of historical colonial connection. Indonesia suffers a capital loss of over $\$ 12$ per $\$ 1$ loan or equivalent to $1.52 \%$ of GDP. Monetizing these, could finance electricity access improvement for 1.75 million poor households, provide a subsidy, and help eliminate SAIDI/SAIFI. Despite it is easy, it requires a fundamental change to fix this.
\end{abstract}

Keywords: Development bank, disbursement delays, energy poverty, money creation, negative impact, aid volatility.

\section{INTRODUCTION}

OECD $^{1}$ (2003) discovered that donors' disbursement delays are among the five most onerous practices that cause aid ineffectiveness. Many studies classified disbursement delay (lag and lead) as a minor issue (Pallage and Robe, 2001:10). Other authors empirically proven the "disbursement delays approach" by donors is one of the main causes of aid volatility (Diarra, 2011:7). Citing Doucouliagos and Paldam (2015:325), Sogge (2017:36) exhibits many donor-biased aid-related studies because of financial supports. Notwithstanding many aids ineffectiveness studies that are grounded on disbursements, there is still no unequivocal reference that shows disbursement delays only are the elementary cause of loan projects' ineffectiveness in reaching the mainstreamed development grandiloquence. To date, to the best of our knowledge, there is none from banking theories and practices and their ramifications on energy poverty. Our paper is bridging this gap and centering upon disbursement delays impacts on energy projects funded by ADB loans in Indonesia.
The poverty and wealth distribution issues are not new and many have addressed them. The literature in the development areas since the 1940s is rich. Not much has changed in terms of wealth distribution, poverty, and its connections to debt. Our paper is dealing with energy poverty issues from a debt perspective on Indonesia's energy projects funded by ADB loans. We consider ADB loan fundsbecause of disbursement delays - as national wealth being retained and utilized by external entities without benefiting Indonesia, hence wealth leakages or capital flight.

The former managing director of the World Bank, Sri Mulyani $(2015)^{2}$ expresses that addressing the energy poverty issue, is ending overall poverty. The issue is not just access to electricity, but highly unreliable services marked by one in three developing countries experience at least 20 hours of power outages per month ${ }^{3}$. Thus, access to energy is critical to ending poverty. She expounds that just improving energy efficiency, eliminates the link between economic growth and energy demand. She highlights the problem in providing energy access that is not just financial but also political. Let

\footnotetext{
3 This is normally measured by SAIDI or SAIFI
}

\footnotetext{
The Organization for Economic Co-operation and Development

What you need to know about energy and poverty (worldbank.org).

https://blogs.worldbank.org/voices/what-you-need-know-about-energy-

and-poverty (27 Jan 2021)
} 
alone the lack of funding either because of no recourse for borrowing or guaranteed continuous flow of funds without disbursement delays. We are using finances and disbursement delay politics and their correlations with poverty as the basis for this paper.

Indonesia has a long history of poverty because of over 300 years of Dutch colonization which ended in 1945 when Indonesia gained its independence. Indonesia has been pressing to eradicate poverty including becoming ADB's member in 1966. Since then, Indonesia has been experiencing disbursement delays in almost all its loans from ADB. Our empirical observations on disbursement delays show that because of them the energy poverty begets more poverty. As Zonday (2018) verbalizes, "poverty charges interest". The interests are beyond financial such as long-duration withunreliable or without electricity for lighting impairs eyes' health and reduces reading and learning ability for children and adults alike. This positions the community or country to a longer-term risk of national human capital degradation hence threatens their existence and could pose them into prolonged poverty, slavery and servitude.

We argue that the inducer of increased energy poverty in Indonesia is restricted financial access via disbursement delays. Here, we define energy poverty as the situation that poor households or communities that do not have sufficient, and regular access to the basic or energy services for their daily living requirements. We will show that 5-year ADB loans disbursement delays, heighten energy poverty incidence relevant to the size of ADB loans, expressed in \% of GDP. These are measured against the full disbursement of $100 \%$ in year-1 into Indonesia's banking sector and in the national currency of Rupiah.

Our finding suggests that loan funds disbursement delays beyond 5 years and incorporating fees and compounded interest, likewise the financial costs of delays under the Loanable Fund (LF), are increasing poverty. Fauzi and Ingratubun (2020) show that financial losses as capital flights because of disbursement delays are over ten times the loan values under fractional reserve banking (FRB) theory. If we capitalized and endogenized them for Indonesia, these delays would decelerate growth into negative (Fauzi and Ingratubun, 2020), triple unemployment (Ingratubun et al., 2021), and raise energy poverty by more than three times. Furthermore, delays hamper Indonesia's ability to provide the muchneeded service delivery improvements measured using $\mathrm{SAIDI}^{4}$ and/or SAIFI ${ }^{5}$, subsidies, and safety net provisions for the lower-income households. Thus, ADB loans, as capital sources, with or without delays have zero impact on increasing growth, reducing unemployment, and eradicating energy poverty. But worsen them all together. Our paper is addressing the linkage between ADB energy loans and Indonesia's energy poverty.

\footnotetext{
System average interruption duration index

System average interruption frequency index

6 Development Outcomes Attribution (DOA) on Bank Outlays Growth Ondevelopment Results (BOGOR) (Ingratubun, 2020).
}

The following sections discuss the Dutch curse, aid volatility, poverty, and energy poverty definitions, ADB implementation delays, and Indonesia's capitals in ADB. The foundational theory of the negative effect of disbursement delays on growth, poverty, and unemployment, a literature review on aid volatility and their costs per U.S. dollar, a brief description of capital endogenization, and three theories of banking and practices as the cornerstone of our paper. Succeeding this, an elaboration on the novel methodology of DOA-BOGOR ${ }^{6}$, discussion on the results, and followed by recommendations.

\subsection{Dutch Disease In Reverse (Dutch Curse)}

The Dutch disease, or natural resource curse, describes the causal relationship between economic development growth in one sector and a reduction in another because of capital inflows. The putative theory suggests that as national incomes grow, inclusive of debt capital, foreign capital inflows accelerate the appreciation of the national currency measured against the exchange rate stability. The expected impactsamong others - growth acceleration, an increase of employment and revenues streams, and poverty reduction. Contrary to the depiction of Dutch disease, especially with the capital inflows, employment creation, and poverty eradication, Indonesia endures capital outflows, not only throughout Dutch colonization but also from ADB loans (Fauzi and Ingratubun, 2020). This is because of its notorious delays in loan fund disbursement that could take, on average, 7 -years into the economy of Indonesia, which in most cases are not $100 \%$. Thus, we term this Dutch Curse as a Dutch disease in reverse because of Indonesia's colonial connection.

\subsection{Aid $^{7}$ volatility, poverty, and energy poverty definition}

Most authors generalize aid volatility as the difference between commitment and disbursements (Pallage and Robe, 2001; Bulír and Haman, 2006; Eifert and Gelb, 2005). Others refer to aid conditionalities (Bulír and Lane, 2004) and shortfalls (Celasun and Walliser, 2008). These authors tackled disbursement as the main predictor and the majority are using econometrics approaches and the rest with descriptive elaboration.

We focus on ADB loans to Indonesia and define aid volatility because of disbursement delays. Keeping in mind prevailing theories of banking and practices, we assess this by the deviation between full loan disbursement in year-1 versus planned and/or actual fund outlays. We did the analysis using a non-econometric but empirical methodology adopting graphical and numerical explorations.

\footnotetext{
7 Loans, grants, technical assistance (TAs), and in-kind assistance is categorized as aid (OECD, 2020). https://data.oecd.org/oda/net-oda.htm (25 Aug 2020)
} 
We adopt the poor or poverty definition by the World Bank that is poverty headcount ratio at $\$ 1.90$ a day (2011 PPP) expressed in \% of the population (Dataset: SI.POV.DDAY). Poverty headcount ratio a day "is the percentage of the population living on less than $\$ 1.90$ a day at 2011 international prices."

\subsection{Energy Poverty}

Energy poverty is a term first introduced by the World Economic Forum in 2010 under Energy Poverty Action. It defines energy poverty as "the lack of access to sustainable modern energy services and products." This includes "a lack of adequate, affordable, reliable, quality, safe and environmentally sound energy services to support development." (Habitat for Humanity, 2020).

The International Energy Agency (IEA) ${ }^{8}$ (2020) measures energy poverty when energy spending is more than $5 \%$ of income. At this level, it considers a household is at risk of losing the ability to pay the energy consumption, which subsequently places it in energy poverty.

ADB appears does not have a definition of energy poverty. The World Bank expresses energy poverty to mean access to power by the poor people who are more likely to stay poor if they continue unconnected (Mulyani, 2015) ${ }^{9}$. Indonesia uses IEA methodology to define energy poverty as the energy access that is a situation in which poor households become unable to afford basic electricity services (Sambodo, $2020)^{10}$.

Albeit, many definitions of energy poverty, most of them point to the lack of access by the poor people to reliable energy sources such as electricity, fuel for transportation and cooking, energy for cooling and warming including for industrial uses. Hence, we confine the definition to mean access deficiency to dependable electricity sources for the population, particularly the poor, for their daily living requirements. This covers not only the total absence of electricity - as with no generation units and distribution networks - but also interruptions in the service deliveries within the existing electricity generation and distribution infrastructure.

\subsection{ADB Disbursement Delays}

ADB, like all development banks, operates like traditional banks (Mazzi, 2013: xxvi). However, borrowing from a commercial bank the borrower gets the credit money disbursed in full upon the Loan Agreement (LA) signing. ADB does not work like this. It takes between 5-10 years to a full disbursement of the loan fund (Figure 1).

The ADB links its disbursements with conditionalities and operates the borrowers' loan account. A former World Bank staff member lambasts that conditionality in whichever formats have failed in Africa and they were designed to fail

\footnotetext{
8 Defining energy access: 2020 methodology.

https://www.iea.org/articles/defining-energy-access-2020-methodology (25 Jan 2021)

9 See footnote 2
}

as a systemic mode to ascertain aid keeps flowing (Kanbur, 2000: 413-416). Conditionality implies the real issue that is "one of an unhealthy interaction between donor and recipient processes which propagate aid dependence but are not so simple as to be characterized as the strength of the donors and the weakness of the recipients." (Kanbur 2000:414). Howarth (2017:33) complements that the use of conditionality is highly contentious, and ineffective.

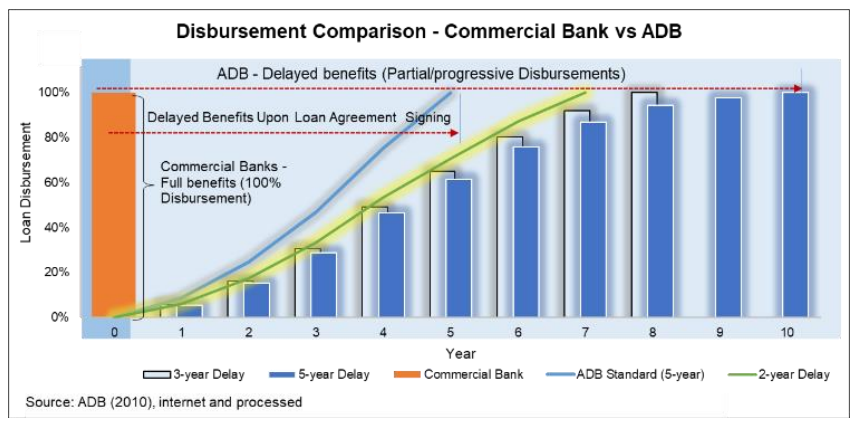

Figure 1. Disbursements Comparison

The ADB's President Nakao affirms that about $90 \%$ of ADB loan projects are seeing 2-year delays (Witular, 2016). Thus, our empirical analysis applied 5-year with 2 years of delays (7-year).

\subsection{Indonesia Capitals in $A D B$}

The ADB - as a quasi-government-requires an establishment act, which each member countries have to ratify by their national law. Accordingly, Indonesia ordained Law No.4/1966. This shelters ADB with no competition in Indonesia. Block (1988:3) extracts that when the government provides a legal position to an entity and authorizes a law that allows it to bypass the competition and anti-monopolies rule and regulations, it creates unemployment. Block contends that " $[i] n$ almost every case, government programs are the cause of joblessness" while the United Nations conveys that joblessness and underemployment are the main drivers of poverty (UN, 2012:3-4). Ingratubun et al, (2021) detect an increase in unemployment by $300 \%$ because of ADB's disbursement delays.

Indonesia has a much larger disbursement capacity of $14 \%$ of GDP compares with the average Indonesian loans from ADB of $0.415 \%$ of GDP or equivalent less than $0.1 \%$ of GDP disbursement/year. Assuming ADB disburses 15\%-20\% of the loan amounts per year, this gives a ratio of $1: 225$ 1:169 being Indonesia having a much larger capacity (169225 times per year) than ADB. Despite these, and over 500\% collateral, the ADB is asserting on controlling, thus delaying, the disbursement following its Charter, Article 14 rendition. Awkwardly Indonesia agrees.

\footnotetext{
${ }^{10}$ FKP 20200416 - Energy Poverty under the Jokowi Presidency. https://www.youtube.com/watch?v=TciViQ7BvNw\&feature=emb_title\& ab_channel=ANUIndonesiaProject (25 Jan 2021)
} 


\section{LITERATURE REVIEW}

\subsection{ADB Energy Projects Portfolio in Indonesia}

The ADB energy lending operation in Indonesia was the second-largest in volume ( $24 \%$ of the total portfolio since 1969) (ADB, 2019a). It comprises 15 sovereign loans, 3 grants, 14 non-sovereign loans, and 19 Technical Assistance (TA) projects. It includes five Policy-based lending (PBL) and two results-based-lending (RBL) operations. It covers power transmission and distribution network improvements, renewable power generation, and policy reforms. (ADB, 2019b: xvii). Overall, ADB's self-evaluation rated its energy portfolio as relevant, effective, likely sustainable, and they satisfactorily meeting their development impacts (ADB, 2019b:35-38).

\subsection{Indonesia Energy Access Overview}

Indonesia has a $99.2 \%{ }^{11}$ electrification ratio, with approximately 2.3 million households remained without electricity or with limited intermittent supply. By March 2020 , there are 26,42 million $^{12}$ poor people, or equivalent to 5.2 million households. This shows that about half of the poor households are not electrified. Per capita, electricity consumption in 2020 is 1,085 kilo-watt-hour $(\mathrm{kWh})$ which is $95 \%$ of the national target of $1,142 \mathrm{kWh}^{13}$. ADB (2020a:19) reports that Indonesia suffers power supply interruptions up to 24 hours per year that affect the reliability of its services. The system average interruption duration index (SAIDI) shows 36 hours per year.

The ADB highlights Indonesia's major issues in providing reliable electricity such as implementation delays and unrealistic load forecast (ADB, 2020a:19-22). Electricity subsidy in 2020 of Rp.92.2 trillion $^{14}$ ( $\$ 6.4$ billion at Rp14,500 per $\$ 1$ ), or $3.63 \%$ of the national budget.

\subsection{Aid volatility, growth, unemployment, and poverty}

Many studies have shown the inter-linkages between electricity access and improvement of living standards as a milestone for poverty eradication (Munasinghe, 1988; Reiche, Covarrubias and Martinot, 2000; Peng and Pan, 2006; Kanagawa and Nakata, 2008, Sambodo et al., 2016).

Despite unemployment and underemployment are the primary inducers of poverty (UN, 2012:3-4), there is worryingly scarce literature that deals with the aid nexus with unemployment and poverty. This may be because of the preferred linkages between aid and employment when the literature is discussing growth. Easterly (2006) found the inverse correlations between aid and growth. He expresses

\footnotetext{
${ }^{11}$ Indonesia's electrification ratio 99.20 percent in 2020

https://indonesiawindow.com/en/indonesias-electrification-ratio-99-20 percent-in-2020/

12 Badan Pusat Statistik

https://www.bps.go.id/pressrelease/2020/07/15/1744/persentase-

penduduk-miskin-maret-2020-naik-menjadi-9-78-persen.html (25 Jan 2021).
}

that there is a disconnection in aid policy based on the assumption that aid promotes growth, which in reality is the opposite (Easterly, 2006:35-41).

\subsection{The impact of disbursement volatility}

Doubling aid volatility leads to a drop in average GDP growth by two-thirds (67\%) (Aldashev and Verardi, 2012:34). Applying $\$ 1$ aid invested by donor countries as a standard of volatility shows between 15\%-2400\% (Jepma, 1991; Andrews and Wilhelm, 2008; GFI et al., 2015; ANU, 2017; Lotti and Presbitero, 2019; Hickel, 2019). The U.S. Congress (1968a: 280) record on ADB shows that "we find that many of the members... put in $\$ 1$ and get out $\$ 7$ [or 700\%].” For interest payment exclusively, it depletes $0.8 \%$ of GDP, and total capital flights are 7.6\% of GDP (Griffiths, 2014).

\subsection{Capital Endogenization}

Interest earned on ADB undisbursed loan amounts and fees incurred are profits for the ADB and/or its private bank and not accounted for as Indonesia's national income (Paradox of profits). For monetization of those gains for the benefit of Indonesia before endogenizing them, we need to consistently treat them as a source of capital (Zezza, 2011:15) for Indonesia. Capital endogenization is a common practice in estimating regional economic wealth outflows (Rustiadi et al., 2018) and development sustainability (Fauzi, 2019).

\subsection{Foundation: Banking Theories, Practices and Governance}

Bourguignon and Sundberg (2007); and Edwards (2014) have sounded the need to go outside of econometrics to unfastened the black box of development aid. This is because many aid studies remain inconclusive. Since no cross-border financial transactions could take place in the world without necessitating banking systems (GFI et al., 2015), we build our foundation on banking practices, rather than econometrics. Galbraith (1975:5) expresses that the knowledge of how the banks work is essential. He says that "[t]he studies of money, above all other fields in economics, is the one in which complexity is used to disguise truth or to evade truth, not to reveal it. ... Money, in contrast, is equally important to those who have it and those who don't. Both, accordingly, have a concern for understanding it."

\subsubsection{Loanable Funds (LF) or Financial Intermediation Banking}

LF is the most propagated theory, which accepts that banks are simply financial intermediaries. They collect deposits from patient savers and lend them to customers and commission interest. ADB appears to practice this as it

\footnotetext{
13 Pandemi Covid-19 Gerus Target Konsumsi Listrik 10 Tahun ke Depan. Suci Sedya Utami, 13 Januari 2021 18:50.

https://www.medcom.id/ekonomi/bisnis/8kolPWRK-pandemi-covid-19gerus-target-konsumsi-listrik-10-tahun-ke-depan (25 Jan 2021)

14 APBN 2020 Direvisi Lagi, Subsidi Energi Dipangkas Rp 5,3 Triliun (kompas.com)

https://money.kompas.com/read/2020/06/04/135303226/apbn-2020direvisi-lagi-subsidi-energi-dipangkas-rp-53-triliun (25 Jan 2021)
} 
unremittingly asking its member countries to refill its ordinary capital resources.

\subsubsection{Money Multiplier or Fractional Reserve Banking (FRB)}

The FRB theory adopts that the banks create money via deposit expansion via the multiplication of a fraction of the assets in their control as the basis for credit generation. For example, a bank with $\$ 100$ cash in its entire holding can lend $\$ 1000$ (10 times) under the $10 \%$ reserve rule ${ }^{15}$ (Nichols, 1992 ( $1^{\text {st }}$ ed., 1961:11)). In 1966, when the ADB was established, the $\mathrm{FED}^{16}$ required all banks to sustain a reserve ratio of 4$6 \%$ (The Fed, 2020, Footnote 10-13). On 26 March 2020, The Fed nullifies this requirement (The Fed, 2020). This means any bank operates and lends money with zero reserves (Nichols, 1992:3). Per ADB's 2020 Information Statement, it appears to maintain between $4-8 \%$ reserve ratio (ADB, 2020b)

\subsubsection{Credit Creation (CC)}

Third, the CC is the most dominant theory and is currently practiced around the world in which banks require neither deposit nor reserve. The Bank of England describes the money creation begins when a client signs the LA. They state that "The bank, therefore, creates its funding, deposits, in the act of lending, in a transaction that involves no intermediation whatsoever." (Jakab \& Kumhof, 2015: ii). All the banks need is a signed LA or promissory note for credit money creation. Based on 5000 years of practice, this is the oldest banking theory in modern civilization (Werner, 2016; Hudson, 2018). Werner (2014:14) conducted the first-ever practical empirical test of modern banking. He discovered in real-time and in a genuine banking environment with a $\mathrm{BBC}^{17}$ crew filming the entire process of LA signing until he received the credit money into his bank account. The entire process took 35 minutes in contrast with the fund outlaying by ADB that takes over 5 years or an average of 7-8 years.

Caveat: For these banking theories and practices benefiting the borrowers, the loan funds must be deposited within the national banking systems and in the local currency (Werner et al., 2011).

\section{METHODOLOGY}

We applied a quantitative attribution method identified as Development Outcomes Attribution (DOA) on Bank Outlays Growth On-development Results (BOGOR) (Ingratubun, 2020). This method adopts a triangulation - a principle widely used in geodetic and geo-positioning (e.g., GPS) sciences - of the results which give a 3 (or more)-dimensional view of the outcomes. DOA-BOGOR treats a scenario of $100 \%$ loan disbursement upon LA signing ${ }^{18}$ in year- 1 as the

\footnotetext{
${ }^{15}$ Adopted based on Indonesia, Article 62.b, Law No.23 (1999) on Bank Indonesia.

${ }^{16}$ Federal Reserve Bank, the central bank of the US.
}

benchmark. Based on the project's progress S-curve, we compared it with progressive disbursement and integrating money creation, their compounded interests, and fees from undisbursed amounts. We triangulated the results from the numerical, graphical, and stochastic agent-based modeling (SABM) approaches. The numerical method is arranging data in a time series and, following Figure 2, calculating the impacts of delays using $100 \%$ disbursement in year-1 as the benchmark. The graphical method involves plotting and interpreting the results from the numerical exercise. Because of SABM's scope that is beyond this paper, we substitute it with the Pilot's view. The pilot's view is taking an overall picture covering a 46-year of ADB energy loan projects in Indonesia.

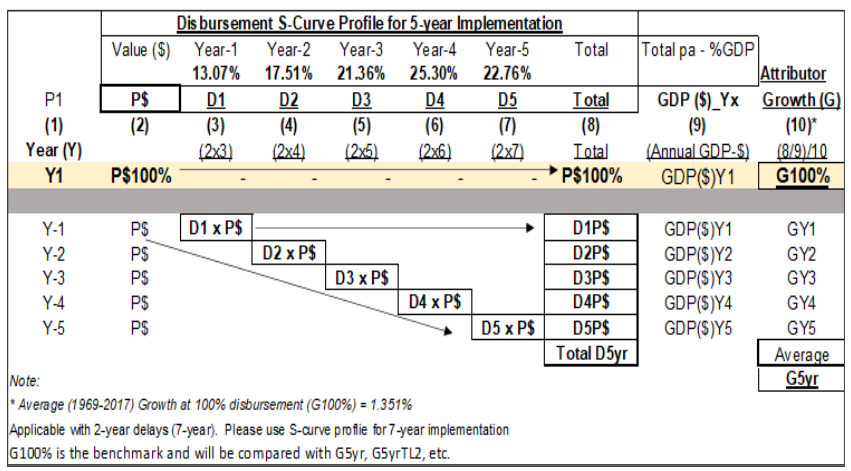

Figure 2. Basic Mechanics of the Attribution method (DOABOGOR)

\subsection{The Philosophy of DOA-BOGOR}

We define attribution in DOA as taking a slice of economic development (i.e., preferably current GDP) indicators and examining their compositions most relevant to the project/program, assessing and understanding their outcome apportionments to the source of funding, which is ADB loans. Using these equations,

$$
\begin{aligned}
& x_{n}=(A / p)_{n} \\
& \bar{x}=\left(\frac{\sum_{1}^{n} f\left(x_{n}\right)}{n}\right) /_{\bar{p}}=\left(\frac{\sum_{1}^{n}(A / p)}{n}\right) / \bar{p}
\end{aligned}
$$

where: $x_{n}=$ Annual energy poverty attributor; $\bar{x}=$ Overall energy poverty attributor; $A=$ $A D B$ loans; $p=$ energy poverty; $\bar{p}=$ mean energy poverty

We get an average value (1971-2017) on an annual project basis of 0.127 poverty level over average poverty of 45.371 (Appendix-A) hence, the ADB loans slice attributes a $0.28 \%$ poverty of Indonesia (Appendix-B). This means ADB energy loans - with an average of $0.127 \%$ of GDP - attributes to about $0.30 \%$ of poverty in Indonesia. We term this as an

\footnotetext{
17 The British Broadcasting Corporation, https://www.bbc.com/

18 Keeping in mind that a signed LA is a promissory note and within the same day creates new money and generates gains thereupon.
} 
energy poverty attributor. Figure 2 illustrates the basic mechanics of DOA-BOGOR.

\subsection{Theory/calculation}

\subsubsection{Theory and Hypothesis}

Ibnu Khaldun, in the $14^{\text {th }}$ century preceding all Nobel Prize winners, warned that when the ruler (government) is not spending money, it is engendering capital shortage. "Now, if the ruler keeps it to himself [undisbursed], it is lost to the subjects." (Khaldun, 1377:365)" Similarly, ADB loans, if disbursed into Indonesia, correlate to capitals, greens, and fertile soils (Khaldun, 1377). Hence, as the ADB loan funds remain undisbursed, it is a loss to Indonesia. This loss is draining Indonesia's wealth, reduces growth, increases unemployment and poverty.

\subsubsection{Description}

We quantitatively measured poverty as an attributor as ADB loans (DOA) outlay progress following S-curve profiles until they reach $100 \%$ (BOGOR). The financial cost of delays of about $30 \%$ and $250 \%$ for LF and FRB respectively after we capitalized and endogenized them as Indonesia's capital. This means we benchmark the costs of delays against the $100 \%$ outlays in year- 1 wherein there is no delay as in disbursement from a commercial bank.

Applying a 10\% bank reserve ratio per the central bank of Indonesia (Bank of Indonesia) ${ }^{19}$, we then ascribed attribution with ADB energy loans (0.127) as a percent (\%) of Indonesia GDP $^{20}$ being the numerator over national poverty ${ }^{21}$ level equally weighted (linearized) annually. From this, we get an energy poverty attributor of $0.0096 \% \sim 0.01 \%$ (Appendix-B). Factual disbursement profiles were used to produce a normalized S-curve profile following the implementation plan with 2-5 years delays (Table 1).

Table 1. Normalized ADB Disbursement S-curve Profiles (2008-2017)

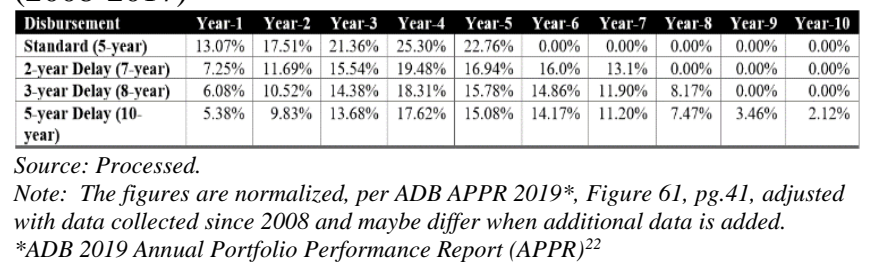

We spread the ADB loans into succeeding 5 and 7-years according to their disbursement profiles per its actual or projected S-curve. Thus, using equation-1 and 2, and Figure

\footnotetext{
${ }^{19}$ Undang-Undang Republik Indonesia Nomor 23 Tahun 1999 Tentang Bank Indonesia

${ }^{20}$ Current GDP in US\$

${ }^{21}$ Poverty headcount ratio at $\$ 1.90$ a day (2011 PPP) (\% of population)

$22 \mathrm{https}: / /$ www.adb.org/sites/default/files/institutionaldocument/603541/appr-2019.pdf (Accessed 5 Jan 2021)

${ }^{23}$ The London Inter-bank Offered Rate (LIBOR)

${ }^{24}$ ADB Operations Manual OM Section D1/BP (Ordinary Capital Resources) https://www.adb.org/sites/default/files/institutionaldocument/31483/om-d1.pdf (Accessed 5 Jan 2021)
}

2 , we derived the energy poverty attributor of $0.0031 \%$ (5year) and $0.0028 \%$ (7-year) and compared them with $0.01 \%$ (at $100 \%$ disbursement in year-1). We adjusted the actual interest rates, $\mathrm{LIBOR}^{23}$, and fees per the banking rules of ADB ${ }^{24}$ to calculate the compounded amounts from undisbursed funds. Adopting the Stock-flow consistent (SFC) model principle of double-entry to balance the money created and its multiplication from the LA date, we then monetized and endogenized them under LF and FRB.

We adopted a simplified approach ${ }^{25}$ by using $1.3(30 \%)$ and $12.5(1250 \%)$ for LF and FRB, respectively. We use them as multiplicators on ADB loans ( $\%$ of GDP) at $100 \%$ disbursement in year-1. From this, we get the energy poverty attributor of $-0.099 \% \sim-0.10$ (LF) and $-0.16 \%$ (FRB). Negative signs show endogenized sources. For estimating future total loan principal plus interest, using an average ADB loan (all projects including energy) interest rate of $4.727 \%$, we adopt the Rule of 70 with 22-year as the average loan life and average ADB energy loans since 1971 of $0.127 \%$ of GDP. Hence $\{2 \times 0.127 \times 22 /(70 / 4.727)\}=0.38 \%$ of GDP which value is in between $2 \%(0.16 \%$ of GDP) and $5 \%(0.40 \%$ of GDP) interest rates.

\subsubsection{Data}

Time-series datasets from $\mathrm{ADB}^{26}$ (Appendix-C), World Bank $^{27}$, Ministry of Finance (MOF) of the Government of Indonesia (GOI), and St. Louis Fed (FRED). ${ }^{28}$ The World Bank data provide the poverty level (Dataset: SI.POV.DDAY) and current GDP (NY.GDP.MKTP.CD). FRED data caters to various interbank lending rates. Poverty data for Indonesia start in 1984 with gaps. We fill these gaps by interpolating or taking them from their neighboring values. Notwithstanding that our analysis used a filled dataset, we present two different graphs showing ADB energy loans impacts on Indonesia's poverty with and without data filled.

We obtained an ADB energy loans portfolio in Indonesia from total $\mathrm{ADB}^{29}$ loans covering 325 (Loans No.0012-3561) with over 1,100 sub-loans, from 1969 to 2017 totaled over $\$ 33$ billion (Appendix-C). The energy loan projects comprised 34 projects with a total of $\$ 5.19$ billion or $15.6 \%$ of total Indonesia's loans from 1971-2017. As of 31 December 2017, about $\$ 1.4$ billion remains undisbursed since 2013. One project (Loan No.2805) is eliminated from the list as it was never signed by the GOI.

\footnotetext{
${ }^{25}$ Ideally, subject to the availability of actual yearly disbursement data, they should be treated as the project progresses under S-curve profiles with compounded interest and fees on undisbursed sums added.

${ }^{26}$ Source: https://data.adb.org/dataset/statement-adbs-sovereign-loans1968-2017 (11 Dec 2020)

${ }^{27}$ Source: World Bank Open Data https://data.worldbank.org or https://data.worldbank.org/topic/economy-and-growth (11 Dec 2020)

${ }^{28}$ Source: https://fred.stlouisfed.org (11 Dec 2020)

${ }^{29}$ Source: https://data.adb.org/dataset/statement-adbs-sovereign-loans1968-2017 (11 Dec 2020)
} 


\section{RESULTS AND DISCUSSION}

\subsection{Findings}

Despite Indonesia's national poverty level has dropped from $68.5 \%$ in 1984 to 4.5 in 2017 (or a reduction of $93.4 \%$ ), ADB loans attribute to an increase in energy poverty from an average of $42 \%$ to $55 \%$ (or $31 \%$ increase) (Figure 3). In any case, as ADB energy loans (\% of GDP) increase, they correlate with increasing poverty and disbursement delays cause more poverty. Contrary to their self-assessment (ADB, 2019b:35-38), this suggests that ADB energy loans are not effective in meeting their development outcome of poverty

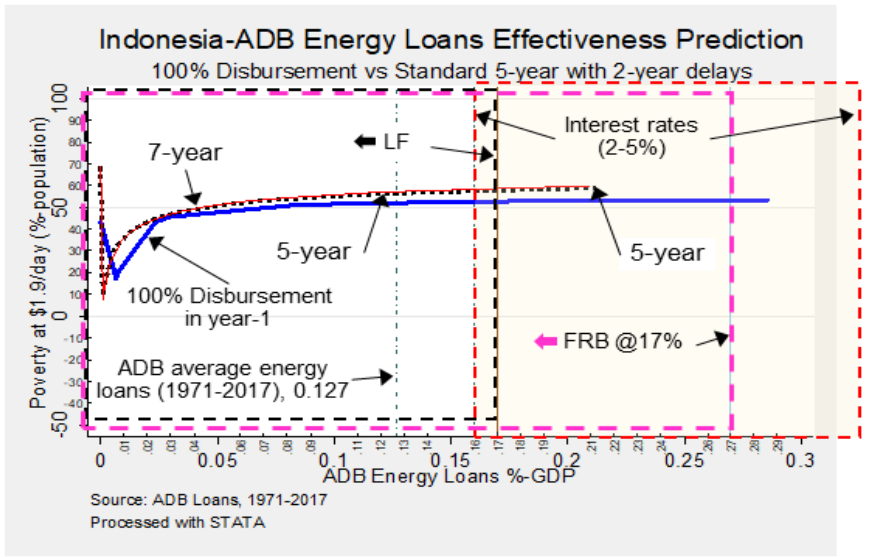

eradication.

Source: World Bank poverty dataset (SI.POV.DDAY, 2021) and ADB Energy Loans to Indonesia (2020)

Figure-3. STATA's Predictions with Fractional Polynomial on ADB Energy Loans Effectiveness vs Indonesia energy poverty.

\subsection{DISCUSSION}

\subsubsection{Pilot view}

Figure 4 provides the pilot's view from which we see volatilities of $60 \%$ because of 5 and 7-year delays. The endogenized costs of which are causing over $130 \%$ and $200 \%$ volatility under LF and FRB at $17 \%{ }^{30}$ correspondingly. This tells us that loan disbursement delays in energy projects are begetting between 0.3 to 2 times more poverty for Indonesia despite the national poverty level has been declining. ADB disbursement delays undermine the effectiveness of their energy loans by over $60 \%$ which means, only less than $40 \%$ effective, contrary to their self-assessment results. This figure $(<40 \%)$ is an indicator of how much ADB loans are disbursed into Indonesia's economy. The rest $(>60 \%)$ are capital flights experienced by Indonesia from its ADB's energy loans.

Figure 4 reminds us to be careful in selecting the graphs as both lines show a conflicting trend. The linear shows uptrend when the polynomial ( 2 order) exhibits up- then down-trend. On the surface, ADB disbursements delays slowly worsening energy poverty. In the background, the costs of delays are increasing energy poverty even faster and aggravating them until ADB loans at $0.15 \%$ of GDP at $100 \%$ disbursement in year-1. We shall see the relevance of this when we triangulated the results between the three approaches. The Pilot view is preparing us to see the negative impacts of ADB loans and their delays in increasing energy poverty between $30 \%$ and over $200 \%$.

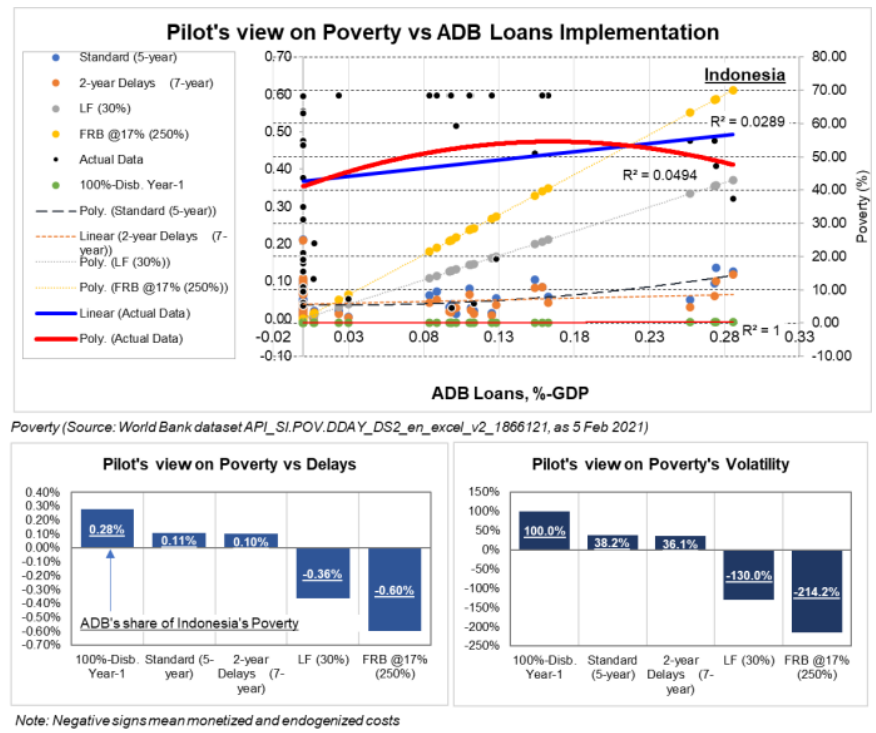

Figure 4. Indonesia Energy Poverty vs ADB Loans Relationship

\subsubsection{Numerical}

Figure 5 shows ADB loans attributed for $0.01 \%$ of energy poverty from the national average of $45.371 \%$ per year under $100 \%$ disbursement upon LA signing in year- 1 .

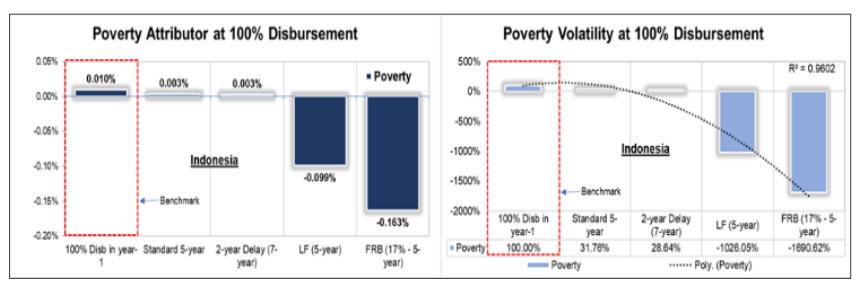

Source: Processed.

Figure 5. Energy Poverty Volatility vs Disbursement Delays

However, the decision not to $100 \%$ disburse in year-1 into Indonesia's economy degenerates ADB loans slice for energy poverty by about $68 \%$ (from $0.01 \%$ to $0.003 \%$ ) hence, exposes the negative impacts of disbursement delays versus $100 \%$ disbursement.

These values are much smaller compared with those under LF (incorporating 30\% compounded interests and fees) and FRB $(250 \%)$ which pulls energy poverty into $-0.01 \%$ and $0.16 \%$ correspondingly, thus over $1000 \%$ volatility. The Rsquared value shows that $96 \%$ deterioration of ADB loan values is relevant to their poverty eradication potentials

\footnotetext{
${ }^{30}$ See Bezemer \& Hudson (2016) on $15 \%$ GDP transactions that contribute to growth.
} 
because of delays. This means the stability of ADB loans in reducing poverty is fewer than $5 \%$. We calculated the FRB impact by considering that $15 \%$ of FRB amounts are for real GDP transactions and contribute to growth (Bezemer \& Hudson, 2016). Hence, to account for transaction costs, we apply $17 \%$ because of the U.S. Dollar denomination, despite in Rupiah it is around $30 \%$ of real GDP transaction after disaggregating Bank Indonesia data.

\subsubsection{Graphical}

After observing data trend lines between linear, quadratic, and polynomial, we selected the fractional polynomial (FP) as an intermediate between non-linear and polynomial (Royston and Sauerbrei, 2007:27). We chose FP over linear regression since its Bayesian information criteria (BIC) is smaller. The BIC values suggest FP is about four times more accurately representing data distribution.

Figure 6 shows the comparison between energy poverty impacts because of ADB loans with and without data filled. It shows ADB loans have severely increased poverty when missing poverty data is not filled. Notwithstanding the impacts, is milder, yet ADB energy loans increase energy poverty. This means ADB energy loans correlate with increased poverty in Indonesia and their disbursement delays causing more poverty hence poverty charges interests because of financial delays.

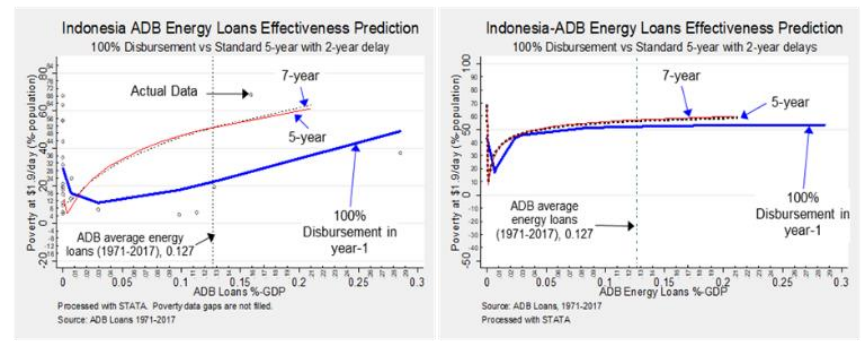

Source: World Bank poverty dataset (SI.POV.DDAY, 2021) and ADB Energy Loans to Indonesia (2020)

Figure 6. ADB Energy Loans Impact on Poverty (Missing data are not filled vs filled)

With the missing poverty data-filled, STATA Twoway graph fractional polynomial function (fpfit) predicted that ADB loans (at $0.127 \%$ of GDP average energy loans from 1971 to 2017), if disbursed $100 \%$ in year-1, while they initially reduce $60 \%$ poverty from $42 \%$ to $17 \%$ until $0.006 \%$ of GDP, the effects are reversed and worsened by $68 \%$ (or three times) beyond $0.024 \%$ of GDP. These are further deteriorated by 5 and 7-year delays from $53 \%$ to $59 \%$ or an increase of $11 \%$. Meaning ADB loans with or without delays have no impact at all on reducing energy poverty, which is contrary to their declared mission of poverty eradication. This poses a critical question on the genuineness of their selfassessment results, stating that they satisfactorily meeting their development impacts (ADB, 2019b:35-38).
Our paper shows that increasing ADB loans with their disbursement delays, plus interests cause increasing energy poverty by more than triple from $17 \%$ at $0.006 \%$ of GDP to $58 \%$ at $0.165 \%$ of GDP (LF at 5 -year) or $17 \%$ at $0.006 \%$ of GDP to $53 \%$ at $0.286 \%$ of GDP ( $100 \%$ Disbursement) under prevailing banking theories and practices. This is equivalent to a ratio of $(17 / 58):(0.006 / 0.165)$ or $8: 1$ meaning that for every $1 \%$ of GDP increase of ADB energy loans, it increases energy poverty by $8 \%$.

\subsubsection{Financial Impacts}

PLN estimates a funding gap over 2015-2019 is about $\$ 30.2$ billion (ADB, 2016:13). It can provide at least a quarter of this amount from the capital flight or money created from the total ADB energy loans of $\$ 5.19$ billion. This is with $10 \%$ reserve requirements under FRB and taking 17\% for GDP transactions, which gives $\$ 8.23$ billion. This is more than sufficient to cover the 2020 subsidy to the poor of $\$ 6.4$ billion.

The cost-per-outage-per-customer to rectify losses because of SAIDI and/or SAIFI is estimated at around \$2.99 per sustained interruption with a mean outage duration of 106 minutes (LaCommare and Eto, 2004:26). Hence, to improve energy access by reducing service delivery interruptions, PLN requires 36 hours (SAIDI)/106 minutes (1.77 hours) x $\$ 2.99$ $=\$ 60.81$ per customer. PLN customers in 2020 are 75.7 million, which gives a total requirement of $\$ 4.6$ billion. The capital flights from ADB energy loans because of disbursement delays could help Indonesia eradicating the energy access problem thus reduce energy poverty due to service interruptions.

Assuming the costs per kilowatt new generation is $\$ 1,500$ per kilowatt (EIA, 2017) and 2.3 million households not electrified need at least 450 watts per connection, this yields 1,035 Megawatt. Using the $75 \%$ availability factor, we then estimate the total cost for connecting those households (Table 2 ). This yields a total investment of $\$ 10.9$ billion. The capital flights of $\$ 8.23$ billion can connect $76 \%$ of the 2.3 million households without adding additional costs burdening the national budget. This brings Indonesia closer to $100 \%$ connectivity.

Triangulating all the results, ceteris paribus, the endogenized costs of 2-year delays caused financial losses to Indonesia of at least $1.3-12^{31}$ times the loan value under LF and FRB respectively. We estimated that $70-80 \%$ of the loan amounts are disbursed into Indonesia's economy, and ADB transferred the rest to the international services providers. Das and Serieux (2015:40) approximate between 25\%-40\% are not entering the national economy. This means $5.8 \%-55 \%$ (e.g., $70 \% \times 1 / 1.3$ for LF, or $1 / 12$ for FRB) of the money created including their compounded gains between $\$ 0.57$ (LF)-\$11.5 (FRB) per \$1 loan are capital flight and never entered the national economy.

\footnotetext{
${ }^{31}$ Under ADB’s 4\% reserve ratio, yields $\$ 32$ per $\$ 1$ or 32 times of the loan value.
} 
The problem does not end here as Sogge (2017, citing Ndikumana and Boyce (2011) and van Bergeijk (2010)) finds that about 60 percent of the funds disbursed in the national economy rapidly leaves the recipient country through a revolving door. The total of which is comparable with capital flights of a minimum of $50 \%-300 \%$. This has not incorporated money creation under FRB and $\mathrm{CC}$, which could be over $2500 \% .^{32}$

Table 2. Base Cost Estimate for Electrification Investment

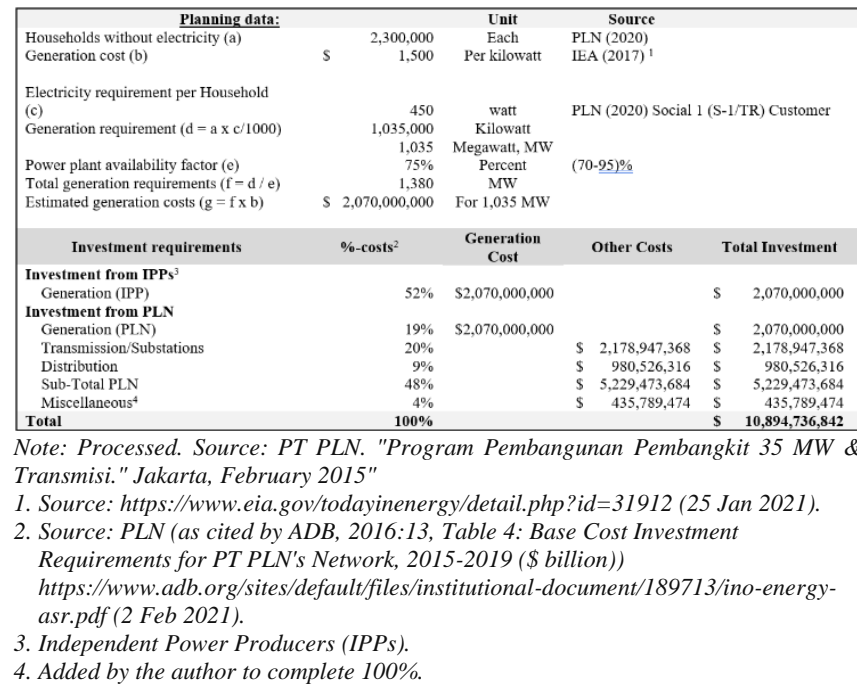

It correlates with our finding for Indonesia with $50 \%$ $1200 \%$ volatility measured against $100 \%$ disbursement in year-1. This means that Indonesia endures a capital flight of $4.98 \%$ of GDP for its total ADB loans (equivalent to $1.524 \%$ of GDP for energy loans). This is smaller than $7.6 \%$ of GDP (Griffiths, 2014) but is almost double the expected return of $700 \%$ (or $2.91 \%$ of GDP) per $\$ 1$ by developed member countries in their investment in ADB (U.S. Congress, 1968a:280). This displays it is not incidental to the ADB loan volatility through disbursement delays. This appears by design, as Acemoglu et al. (2001) attribute this as an economic deceleration in less developed countries (former colonies) because of the founding of extractive institutions.

\section{CONCLUSIONS AND RECOMMENDATION}

\subsection{Conclusion}

Energy poverty from ADB loans in Indonesia charges interests not only more poverty but also in financial forms, such as interest gained on disbursement delays, money created through loan agreements, and capital flight. Let alone compounded derivatives of its effects such as loss of human capital. And their negative impacts on growth, unemployment, prolonging, and increasing poverty because of ADB disbursement delays. Fixing this is simple but requires a fundamental shift, and an honest intention beyond

\footnotetext{
${ }^{32}$ See footnote 31

${ }^{33}$ A moral hazard is a situation in which decision-makers maximize their benefits while impairing others because of incomplete information on
}

the political narrative of reducing delays, and genuine efforts to promote growth, reduce unemployment, and eradicating poverty.

\subsection{Recommendations}

Given the availability of sufficient collateral, the GOI critically requires national law and political decisions to have any ADB loan funds $100 \%$ disbursed into the banking systems in Indonesia and Rupiah currency in year-1. Or no ADB loans in foreign currencies at all. In mitigating moral hazard $^{33}$ (Coase, 1960), reforming the governance of ADB loan disbursement. It requires more studies with different attributors, endogenized capitals, and LA conditionalities.

\section{ACKNOWLEDGMENT}

Appreciations and gratitude are expressed to the IPB University, Regional and Rural Development Planning (PWD) Department. For opening a deeper understanding of the true scope of wealth leakages and their critical role in regional development and poverty eradication.

\section{REFERENCES}

[1] Acemoglu D., S. Johnson, and J. Robinson, J. The Colonial Origins of Development: An Empirical Investigation. American Economic Review, 91(5), (Dec. 2001), 2001, pp. 1369-1401.

[2] ADB. Indonesia: Energy Sector Assessment, Strategy, and Road Map. Manila, The Philippines: 2016, Asian Development Bank. https://www.adb.org/documents/indonesia-energysector-assessment-strategy-and-road-map. (25 January 2021).

[3] ADB. 2018 Annual Portfolio Performance Report (APPR). 2019a, Asian Development Bank. https://www.adb.org/sites/default/files/institutionaldocument/500841/appr-2018.pdf. (25 January 2021).

[4] ADB. Country Assistance Program Evaluation. Indonesia, 2005-2018. Manila, The Philippines: 2019b, Asian Development Bank. https://www.adb.org/sites/default/files/evaluationdocument/484386/files/cape-ino.pdf (25 January 2021).

[5] ADB. Indonesia: Sustainable Infrastructure Assistance Program. Subproject 14: Indonesia Energy Sector Assessment and Priorities, 2020-2024. Project Number: 46380-023. TA Number: 9511. Manila, The Philippines: 2020a, Asian Development

Bank. https://www.adb.org/sites/default/files/projectdocuments/46380/46380-023-dpta-en.pdf (25 January 2021)

[6] ADB. 2019 Information Statement. 2020b, Asian Development Bank. https://www.adb.org/sites/default/files/institutionaldocument/417506/information-statement-2020.pdf December 2020).

[7] Aldashev, G., and V. Vincenzo. Is Aid Volatility Harmful? The University of Namur, 2012. https://www.tcd.ie/Economics/assets/pdf/AID_VOLATILITY _Draft_Jan8_2012_FULL.pdf (25 January 2021)

[8] Andrews, M., and V. Wilhelm. Thinking about Aid Predictability. NUMBER 124, PREM Notes Poverty: The World Bank, 2008. 
[9] Australian National University (ANU). Aid study shows every $\$ 1$ spent returns $\$ 7.10$ in exports. 16 October 2017. https://www.anu.edu.au/news/all-news/aid-study-showsevery-1-spent-returns-710-in-exports. (25 January 2021)

[10] Bezemer, D., and M.J. Hudson. Finance is not the Economy: Reviving the Conceptual Distinction. Journal of Economic Issues. 50, 3, 2016, p.745-768.

[11] Block, W. How the Market Creates Jobs and How the Government Destroys Them (Full Edition), 1988. https://cdn.mises.org/fm588_0.pdf (25 January 2021)

[12] Bourguignon, F., and M. Sundberg. 2007. Aid Effectiveness: Opening the Black Box. American Economic Review 97(2): 316-321.

[13] Bulíŕ, A., and J.A. Hamann. Volatility of Development Aid: From the Frying Pan into the Fire? International Monetary Fund. IMF Working Paper, 2006, WP/06/65.

[14] Bulír, A., and T. Lane. "Aid and Fiscal Management," in Helping Countries Develop: The Role of Fiscal Policy, ed. by Gupta, S., Clements, B. and Inchauste, G. (Washington: International Monetary Fund), 2004.

[15] Celasun, O., and J. Walliser. Predictability of Aid: Do Fickle Donors Undermine Aid Effectiveness? Economic Policy, 23(July), 2008, pp. 545-94.

[16] Coase, R. The Problem of Social Cost. Journal of Law and Economics, 3(1), 1960, pp. 1-44.

[17] Das, A., and J. Serieux. Aid and reverse flows: a global analysis, in the M. Arvin \& B. Lew (eds) Handbook on the Economics of Foreign Aid, Cheltenham: 2015, Edward Elgar Publishing.

[18] Diarra, G. Aid unpredictability and absorptive capacity: analyzing disbursement delays in Africa. Economics Bulletin, 31(1). 2011, pp. 1004-1017.

[19] Easterly, W. The White Man's Burden. Oxford University Press, 2006.

[20] Ebrahim-Zadeh, Christine. Back to Basics. Dutch Disease: Too much wealth managed unwisely. IMF Finance \& Development, March 2003, Volume 40, Number 1, 2003. https://www.imf.org/external/pubs/ft/fandd/2003/03/ebra.htm (5 July 2021).

[21] Edwards, S. Economic development and the effectiveness of foreign aid: A historical perspective, 2014. https://voxeu.org/article/development-and-foreign-aidhistorical-perspective (5 July 2021).

[22] Eifert, B., and A. Gelb. Coping with Aid Volatility. A quarterly magazine of the IMF. September 2005, Volume 42, 2005, Number

3. https://www.imf.org/external/Pubs/FT/fandd/2005/09/eifert.ht m. (25 January 2021)

[23] The US Energy Information Administration (EIA). Construction costs for most power plant types have fallen in recent years, 2017. https://www.eia.gov/todayinenergy/detail.php?id=31912 $\quad(25$ January 2021)

[24] Fauzi A. and Ingratubun, M.A. Opening the Black Box: Disbursement Delays Impacts on Growth in Asian Development Bank (ADB) Loan Projects in Indonesia. Online Conscience Conference on Social Sciences and Humanities, 2020. http://society.education/. (25 January 2021)

[25] Fauzi, A. Teknik Analisis Keberlanjutan. PT Gramedia Pustaka Utama, Jakarta, 2019, Indonesia.

[26] Galbraith, J. K. Money, Whence it Came, Where It Went. Boston, U.S.: Houghton Mifflin, 1975.

[27] Global Financial Integrity (GFI) et al. Financial Flows and Tax Havens: Combining to Limit the Lives of Billions of People, 2015.

https://secureservercdn.net/45.40.149.159/34n.8bd.myftpuploa d.com/wp-content/uploads/2016/12/Financial_Flows-final.pdf (25 January 2021)
[28] Griffith, J. Developing countries lose $\$ 2$ for every $\$ 1$ they earn. Eurodad,

https://www.euractiv.com/section/development-

policy/opinion/developing-countries-lose-2-for-every-1-theyearn/?fbclid=IwAR1-

sYzJR0cWMFVtBiaBOuSe3Kp3RWqtlW70wG8f8mgJoGYv 17e4qxTItmU (4 Oct 2021)

[29] Gross, M., and C. Siebenbrunner. Money Creation in Fiat and Digital Currency Systems. IMF Working Paper WP/19/285, 2019. International Monetary Fund.

[30] Habitat For Humanity. What is energy poverty? 2021. https://www.habitat.org/emea/about/what-we-do/residentialenergy-efficiency-households/energy-poverty (25 January 2021)

[31] Hickel, J. Aid in reverse: how poor countries develop rich countries. 2017. https://www.theguardian.com/globaldevelopment-professionals-network/2017/jan/14/aid-inreverse-how-poor-countries-develop-rich-countries January 2021)

[32] Howarth, C. N. Does Development Aid Work? A report by Christopher N. Howarth for the Global Development Challenge. The Project for Modern Democracy, 2017. https://issuu.com/p4md/docs/pmd_aid_effectiveness_report (25 January 2021)

[33] Hudson, M. J. Palatial Credit: Origins of Money and Interest, 2018. https://michael-hudson.com/2018/04/palatial-creditorigins-of-money-and-interest/ (25 January 2021)

[34] Ingratubun, M. A. (Unpublished) Tracking Effectiveness of Loan Funds (Aid) (TEA) through Development Outcomes Attribution (DOA) on Bank Outlays Growth On-development Results (BOGOR). Case Study: Indonesia Loans from the Asian Development Bank (ADB). Bogor, 2020, Indonesia.

[35] Ingratubun, M.A, Fahly, A.P, Cahyadie, B, Nizar, N.I., and Rantini, R.R. Dutch Curse on Indonesia: Unemployment by Asian Development Bank (ADB) Loan Projects. Gadjah Mada International Journal of Business, Vol 23, No 2, 2021. DOI: 10.22146/gamaijb.63409.

[36] Jakab, Z., and Kumhof, M. Banks are not intermediaries of loanable funds - and why this matters. Working Paper No. 529, 2015, May, Bank of England.

[37] Jepma, C. J. The tying of aid, Paris, OECD, 1991.

[38] Kanagawa, M., and Nakata, T. Assessment of access to electricity and the socio-economic impacts in rural areas of developing countries. Policy, 36, 2008, 2016-2029.

[39] Kanbur, R. Aid, Conditionality, and Debt in Africa, in F. Tarp (ed.), Foreign Aid and Development: Lessons Learnt and Directions for the Future, London and New York: Routledge, 2000, 409-22.

[40] Khaldun, I. The Muqaddimah: An Introduction to History. 1377, Translated by Franz Rosenthal (1969). https://asadullahali.files.wordpress.com/2012/10/ibn_khaldunal_muqaddimah.pdf (25 January 2021)

[41] LaCommare, Kristina Hamachi and Joseph H. Eto. Understanding the Cost of Power Interruptions to U.S. Electricity Consumers. Energy Analysis Department, Ernest Orlando Lawrence Berkeley National Laboratory. Berkeley, California 94720. 2004, University of California Berkeley.

[42] Lotti, G., and A. Presbitero. The mobilization effects of multilateral development banks, 2019. https://voxeu.org/article/mobilisation-effects-multilateraldevelopment-banks (25 January 2021)

[43] Sambodo, M.T Negara, S.D and Fuady, A.H. Akses Listrik dan Kesejahteraan Masyarakat. Lembaga Ilmu Pengetahuan Indonesia (LIPI). Jakarta: LIPI Press, 2016. 
[44] Sambodo. KP 20200416 - Energy Poverty under the Jokowi Presidency, 2021. https://www.youtube.com/watch?v=TciViQ7BvNw\&feature= emb_title\&ab_channel=ANUIndonesiaProject $\quad(25$ January 2021)

[45] Mazzi, Biagio. Treasury Finance and Development Banking. A Guide to Credit, Debt, and Risk. New Jersey, USA: John Wiley \& Sons, Inc., 2013.

[46] Munasinghe, M. Rural electrification: International experience and policy in Indonesia. Bulletin of Indonesia Economic Studies, 24(2), 1988, 87-105.

[47] Nichols, D. M. Modern Money Mechanics. A Workbook on Bank Reserves and Deposit Expansion. 1st published in 1961. Last revision by Anne Marie L. Gonczy (1992). Chicago, IL, U.S.: Federal Reserve Bank of Chicago, 1994.

[48] OECD. Harmonizing Donor Practices for Effective Aid Delivery. DAC Guidelines and Reference Series. 2003, (Paris: Organisation for Economic Co-operation and Development, Development Assistance Committee). http://www.oecd.org/dataoecd/0/48/20896122.pdf (25 January 2021)

[49] Pallage, S. P., and M. A. Robe. Foreign aid and business cycles. Review of International Economics 9, 2001, 641-672.

[50] Peng, W., \& Pan, J. Rural electrification in China: History and institution. China \& World Economy, 14(1), 2006, 71-84.

[51] Reiche, K. Covarrubias, A., \& Martinot, E. Expanding electricity access to remote areas: Off-grid rural electrification in developing countries. World Power, 2000.

[52] Royston, P., and W. Sauerbrei. The Use of Fractional Polynomials in Multivariable Regression Modelling. Presentation: Heidelberg, Germany, 2007. http://www.biometrie.uni-heidelberg.de/statmethag/veranstaltungen/magdeburg07/talks/sauerbrei.pdf January 2021)

[53] Rustiadi, E., S. Saefulhakim, and D. R. Panuju. Perencanaan Dan Pengembangan Wilayah. Jakarta, Indonesia: Yayasan Pustaka Obor Indonesia, 2018.

[54] Sogge, D. Foreign Aid: Inconvenient Truths. Sinergias diálogos educativos para a transformação social, junho 2017, No.5, 2017.
[55] The Fed. Reserve Requirements. The U.S. Federal Reserve, 2020. https://www.federalreserve.gov/monetarypolicy/reservereq.ht m (25 January 2021)

[56] U.S. Congress. Appropriation for 1969. House of Representatives. 9th Congress, Second Session, Part 1 (94-105), 1968a, pp.264-324 and 1968b, Part 2 (94-955)-Economic Assistance, pp.25-39.

[57] United Nations (UN). Macroeconomic stability, inclusive growth, and employment. Thematic Think Piece. ILO, UNCTAD, UNDESA, WTO. UN System Task Team on the post-2015 UN development agenda, 2012.

[58] Werner, R. A, Ryan-Collins, J., Greenham, T., Jackson, A Where does money come from? A guide to the UK monetary and banking system. London: New Economics Foundation, 2011.

[59] Werner, R. A. Can banks individually create money out of nothing? The theories and empirical evidence. International Review of Financial Analysis, 36, 2014, pp.1-19

[60] Werner, R. A. A lost century in economics: Three theories of banking and the conclusive evidence. International Review of Financial Analysis, 46, 2016, pp.361-379.

[61] Witular, R. A. Asian Development Bank to reform project delivery, cut delays. The Jakarta Post (Fri, May 6, 2016). https://www.thejakartapost.com/news/2016/05/06/asiandevelopment-bank-to-reform-project-delivery-cut-delays.html (25 January 2021)

[62] Zezza, G. Godley and Graziani: Stock-Flow-Consistent Monetary Circuits. Levy Economics Institute, 2011.

[63] Zonday. Twitter, 2021 https://twitter.com/TayZonday/status/1020003667921940480 (25 January 2021) 